\title{
Consumers' Device Choice in E-Retail: Do Regulatory Focus and Chronotype Matter?
}

\author{
Syed Waqar Haider ${ }^{1, *}$, Zhuang Guijun ${ }^{1,}$ Amir Ikram², Bilal Anwar ${ }^{3}$ \\ ${ }^{1}$ School of Management, Xi' an Jiaotong University, China \\ 2 Institute of business \& management, UET, Pakistan \\ ${ }^{3}$ National defence university, LMS, Pakistan \\ *[e-mail: sw_rizvi@hotmail.com] \\ *Corresponding author : Syed Waqar Haider
}

Received April 19, 2019; revised July 5, 2019; revised July 27, 2019; accepted August 15, 2019;

published January 31, 2020

\begin{abstract}
Today, digital shoppers express increasingly complex buying behavior. They can use multiple channels for shopping and also they can switch from one to another channel almost effortlessly, in the result of engaging in omnichannel shopping behavior. A few years ago, consumers were using brick and mortar stores to make their purchases. However, nowadays, they possess different digital devices (mobile and/or desktop) to search for different alternatives and to make a better shopping choice. These devices (mobile and desktop) are different and offer unique benefits to consumers. However, there has been very little research that has treated mobile and desktop devices separately. Perhaps this study is the pioneer when it comes to investigating the effect of regulatory focus (prevention vs. promotion) and chronotype (morning and evening person) on a sample of university students using desktop and mobile channels for their shopping. The findings from a sample of 312 digital consumers (mobile and/or desktop) confirmed that the desktop channel provides a greater fit for morning-type respondents and that the mobile channel offers better value for evening-type respondents in e-retail. Furthermore, promotion-focused shoppers favor the mobile channel, and prevention-focused shoppers favor the desktop channel. The new insights and contributions of this study provide a better understanding of digital consumers to help sellers to develop a more effective e-retail strategy.
\end{abstract}

Keywords: Mobile Devices, E-retail, Regulatory focus theory, Chronotype, Omnichannel 


\section{Introduction}

The current advances and developments in technology have resulted in a growing number of tech-savvy shoppers showing complex buying behavior. Verhoef, Kannan, and Inman (2015) [1] stated that consumers are displaying more dynamic shopping behavior than before because they are going through an evolutionary stage, moving from the use of a physical store, through multi-channel and reaching omnichannel as the current final result. There are many studies which have investigated the marketing, channel attribute, social and psychological factors driving the consumers' channel choice [2-4]. Furthermore, Ansari, Mela, and Neslin (2008) [3] observed consumer behavior in terms of channel adoption and channel choice. However, online retail is now observing a revolutionary shift from multi-channel to omnichannel because of advancements in the digital shopping channels available such as mobile and desktop channels.

A single channel may be a physical store where customers can search, evaluate, and make a purchase at the same time, or it can be an online selling platform in the form of a website. However, a multichannel retailer may have a website and physical stores. These two channels are generally very siloed and have very little interaction with one another. The best metaphor for a multi-channel is a wheel with spokes. At the center of the wheel is your product (i.e., a sale). On the outer rim of the wheel are your customers where each channel offers a separate and independent opportunity to purchase. Whereas as opposed to the multi-channels wheel, think of omni-channel as an immersion, like diving into an all-inclusive sales-and-marketing pool or pulled into the center of a brand's gravity. In omni-channel, the customer and not the product lies at the core. Omnichannel refers to a blend of physical and digital shopping channels where the consumer can do their shopping at any time and where they can switch channels seamlessly [5,6]. Therefore, marketers are trying to understand the consumers' search and purchase behavior in an omnichannel context [7]. Consequently, research on $\mathrm{m}$-commerce and social commerce is growing [8-11].

It is becoming the new normal to use digital devices for shopping. For instance, in the United States, almost $50 \%$ of retail sales were done using digital devices [12]. The digital devices are used at different levels of the purchase journey, from searching for the product and comparing and evaluating the alternatives through to concluding the purchase. Moreover, the literature mostly focuses on the consumers' choice between offline and online channels for the different shopping stages $[1,13]$. Furthermore, omnichannel advancement has resulted in a spurt in the digital devices used for shopping such as desktop computers, laptops, tablets, and ipads along with smartphones. The literature confirms that desktop and mobile channels have rich differences in terms of screen size, information processing, ease of use, capacity, and personality $[14,15]$. Consequently, just as the previous studies have segregated online and offline channels, the same needs to be done by treating mobile and desktop channels separately.

Furthermore, mobile and desktops also differ in time, place, and context, as mobiles offer quick and location-based search and purchasing, images and voice search capability, continuous connectivity, and fast payment service. The desktop channel provides enhanced content, detailed information, a large screen, and an easy method of evaluation. Taking these differences into account, research which distinguishes between consumer shopping behavior on both mobile and desktop channels remains sparse. Exceptions include the study of Holmes, Byrne, and Rowley (2013) [16], which discovered that channel attribute preference plays a 
vital role between online and mobile channel user differences. The present research incorporates the regulatory focus (promotion vs. prevention) and chronotype (evening vs. morning type) to explain the consumers' device choice in e-retail. According to regulatory focus theory, there are two types of regulatory focus (promotion \& prevention) [17]. The consumer behavior is significantly influenced by regulatory focus orientation [18]. Furthermore, prior research found that evening type chronotype are more close to promotion focus orientation and morning type chronotypes have prevention focus orientation [19, 20], and this association is the motivation of the current study to investigate the impact of these two personality traits on consumer decision making. According to RFT, the promotion-focused individuals orient themselves toward accomplishments, achievements, and development [21]. They are more likely to be impulsive and to seek hedonic motives for shopping [22], and they use mobile channel more often for online shopping. However, Prevention-focused individuals are more concerned about safety, vigilance protection from and of negative consequences of their purchase [21]. They look for detailed information and prefer to have utilitarian shopping value [22].

Furthermore, the different chronotypes represent the differences in individuals' time and sleep habits, which influences their behavior. Previous studies fortify the statement that evening and morning type chronotypes are different in terms of personality and behavior [23]. Evening types mostly wake up late and complete their work in the evening hours, whereas morning types like to wake up early and accomplish the task in the morning [24]. The chronotype has been examined in both the psychological and biological fields [25, 26]. However, it has received less attention in the marketing and business field. Exceptions include the study of Gullo, Berger, Etkin, and Bollinger (2018) [27], which found there to be a correlation between variety-seeking conduct and time of the day and Hornik and Miniero (2009) [28], who stated that chronotype affects ad recall ability and service evaluation performance.

In this respect, there are Regulatory Focus Theory "RFT" and Task-Technology Fit "TTF" theory. According to RFT, customer buying decisions stem from different motivations. These motivations can be categorized on one significant criterion: either the customer is striving to achieve a desired state/goal (promotion focus), or she is determined to avoid an undesired outcome (prevention focus) [29]. These different contrasting types of regulatory foci may influence the consumers' decision making, psychology, and information processing [30]. Furthermore, there are very few studies which investigate regulatory focus theory in the marketing field, and this gap motivates the authors to conduct present research in an electronic retail context. The exceptions include Arnold and Reynolds [21] who investigate the relationship between RFT, mood, and retail environment, and Das (2015) [22] who studied regulatory focus and impulsiveness impact on brand loyalty. Whereas, Task-Technology Fit Theory "TTF" which describes the optimal choice of device used to perform a task, was introduced by Goodhue and Thompson (1995) [31]. In the literature, this theory has helped to explain wireless device adoption [32], location-oriented offerings [33], and online purchase intention [34]. Moreover, the prior research has primarily focused on TTF from the task and technology characteristics perspective [32, 33], but research on how the characteristics of the individual effect TTF remains sparse [35, 36]. The present study examines this under-explored side of TTF, which is how the individuals' regulatory focus and chronotype affect the device choice in order to carry out the search and purchase task in the context of e-retail.

This is likely to be the first study that is aimed at addressing the essential question of how chronotype (morning vs. evening types) and regulatory focus (promotion vs. prevention) can influence the consumers' choice between the mobile and desktop channels when it comes to performing the search and purchase task. The important gaps filled in by this study are that 
while the previous literature deals with omnichannel in terms of online and offline channels, this research incorporates the mobile channel as well. However, it is noteworthy that this omnichannel journey is from consumers' perspective who has access to online (mobile/desktop) and offline channels while the current study only dealing with mobile and desktop channel choice of the consumer in the omnichannel journey. Secondly, this study investigates how personality traits (regulatory focus and chronotype) shape consumer behavior in terms of the channel choice process. Third, is that by analyzing the regulatory focus and chronotype in the omnichannel process, this study provides a better understanding of the digital shopper, which will likely to grab the attention of academicians and businesses alike in future research. While previous studies are mostly in European countries and thus from a Western perspective, this study examines the Chinese market. As according to Borak (2018) [37], in China, more than 85\% of online shopping is done by young consumers aged 17 to 36 years old. Jindong and Taobao have over one billion active shoppers, and these two brands are the most famous and largest online shopping retail platforms in China [37]. In the second quarter of 2017, online retail in China faced an increase in volume and surpassed the US \$132.40 in value. However, Taobao and JD are online retail platforms, where different sellers can offer their product and services by setting up the account on these e-retail platforms. These e-retail platforms can be accessed via mobile and desktop; consumers can make search, evaluate, and make payment to purchase the item. Finally, this study will support both academicians and marketers in understanding the ever-growing base of omnichannel shoppers and to formulate an effective strategy for mobile consumers.

\section{Related Work}

\subsection{Circadian rhythm (Chronotype)}

According to Circadian Typology, there are three types of chronotype; morning, neither and evening. Evening types sleep late and wake up late; they are more active in the evening and have an irregular sleep-wake pattern. Morning types have a propensity to sleep and wake up early, and they are more energetic in the day time. They also show differences in terms of personality, educational performance, work engagement, and so on [38, 39]. Neither types are in between the morning and evening type. The literature shows that evening types are more habituated to computer games, the internet, and mobile phones [20, 40]. All of these characteristics are linked to individual differences such as chronotypes, which may impact consumer device choice for shopping. In their study,

Horzum and Demirhan (2017) [24] confirmed that the users' chronotype affects their attitude toward Facebook usage. Chronotypes have been examined in many perspectives, including technology, behavior, and personality, but it has acquired less consideration in the marketing domain. Furthermore, it will be valuable to examine the link between chronotype and device choice in the omnichannel context.

\subsection{Regulatory Focus}

According to regulatory focus theory, there are two types of regulatory focus (promotion \& prevention) [17]. Promotion-focused individuals orient themselves toward accomplishments, achievements, and development. They are more likely to be impulsive and to seek hedonic motives for shopping [21]. They can make decisions with less and ambiguous information [41]. Prevention-focused individuals are more concerned about protection from and the preventing 
of negative consequences. They look for detailed information and prefer to have utilitarian motives [21]. These contrasting types of focus may influence consumers' decision making, psychology, and information processing [30]. Furthermore, there are very few studies which investigate regulatory focus theory in the marketing field, and this gap motivates the authors to conduct present research in an electronic retail context. The exceptions include Arnold and Reynolds (2009) [21] who investigate the relationship between RFT, mood, and retail environment, and Das (2015) [22] who studied regulatory focus and impulsiveness impact on brand loyalty. This study examines whether the type of regulatory focus (RF) plays any role between chronotype and channel choice behavior.

\subsection{Omnichannel}

Omnichannel refers to a combination of the physical store and digital shopping channels where the consumer can do their shopping at any time, anywhere, and where they can switch channels seamlessly [5, 6]. In the near past, most of the customers used to visit single physical stores in order to search and evaluate the available products. They would conclude their purchase at the same point in time and space. Furthermore, with the advancement of technology, the sellers are offering their products through multi-channels which include offline and online (websites, Apps, Catalogs). However, in a multi-channel environment, each channel works separately, and there is weak interaction, switching capability for customer and uniform service experience. In multi-channel consumers are usually bound to follow the same channel for complete purchase journey as they are not able to switch channels easily. Today, in this fast-growing digital world, now they possess several electronic devices including mobiles, iPads, desktop computers and they have a larger number of touchpoints (mobile apps, websites, social media) where they can search, compare, purchase and recommend products [42]. This new stage of electronic commerce in which the consumer can switch channels almost effortlessly is named the omnichannel age $[5,6]$. This advancement in digital channels presents a greater challenge to marketers and scholars when it comes to an understanding of this new, dynamic, and tech-savvy consumer behavior. Omnichannel is a newly coined term, and it is gaining the attention of researchers. For instance, Blom, Lange, and Hess Jr (2017) [7] presented how omnichannel-based promotions can shape behavior, Horzum and Demirhan (2017) [43] examined how personality traits and differences can affect channel adoptions in the omnichannel context, and Kazancoglu and Aydin (2018) [44] investigated the buying intention of shoppers in the omnichannel perspective. There is a number of points which differentiate omnichannel from multichannel such as the level of channel integration, switching ease, and service consistency [45]. The customer may search for a product on their smartphone, compare and evaluate in the physical store, and conclude the purchase on their desktop. This behavior may vary as every individual has a different personality, different preferences, and is in a different situation. Therefore, this study intends to disentangle the regulatory focus, chronotype, and channel choice relationship for search and purchase purposes in e-retail.

\section{Theoretical Brace}

The customer buying decisions stem from different motivations. These motivations can be categorized on one significant criterion: either the customer is striving to achieve a desired state/goal, or she is determined to avoid an undesired outcome [29]. According to regulatory 
focus theory, there are two types of regulatory focus (promotion \& prevention) [17]. The consumer behavior is significantly influenced by regulatory focus orientation [18]. Furthermore, prior research found that evening type chronotype are more close to promotion focus orientation and morning type chronotypes have prevention focus orientation [19, 20], and this association is the motivation of the current study to investigate the impact of these two personality traits on consumer decision making. According to RFT, the promotion-focused individuals orient themselves toward accomplishments, achievements, and development [21]. They are more likely to be impulsive and to seek hedonic motives for shopping [22], and they use mobile channel seems better fit for their online shopping. However, Prevention-focused individuals are more concerned about safety, vigilance protection from and of negative consequences of their purchase [21]. They look for detailed information and prefer to have utilitarian shopping value [22]. A prevention-focused person usually follows the "thinking before acting" approach, and they score low on impulsivity [22]. The thinking before acting type person well planned and detailed information seeker. They try their best to limit the negative consequences of their actions [46]. The features of the desktop channel (low search cost, easy navigation, and comparison, larger screen, etc.) seems a suitable option for customers with prevention orientation. These contrasting types of regulatory foci may influence the consumers' decision-making, psychology, and information processing [30] and the present study aims to explore how regulatory orientation can influence channel choice in e-retail.

However, Task-Technology Fit Theory “TTF," which describes the optimal choice of device used to perform a task, was introduced by [31]. Technology characteristics denote the devices and instruments used by a person to perform her task. The task characteristics are the actions taken by the consumer in turning their inputs into outputs. Whereas the degree of task-technology fit depends on how much an instrument or device helps the consumer to perform her task [31]. So accordingly, the technology or device (mobile or desktop) will be used to perform search and purchase tasks only if the functions of the device correspond with the tasks to be performed. However, Goodhue and Thompson (1995) [31] model include task, technology, and individual characteristics, but only the first two constructs are tested in their study. The effect of individual characteristics are unclear and no significant effect of individual characteristics are found in their work so they concluded that its' only task characteristics which effect technology fit. In the literature, this theory has helped to explain wireless device adoption [32], location-oriented offerings [33], and online purchase intention [34]. Moreover, the prior research has primarily focused on TTF from the task and technology characteristics perspective [32, 33], but research on how the characteristics of the individual effect TTF remains sparse [35, 36]. Exceptions include Chen and Huang (2017) [34] who investigated the task-technology fit impact on purchase intention and Gupta and Arora (2017) [47] who explored how personality traits affect task-technology fit in m-banking adoption. The present study examines this under-explored side of TTF, which is how the individuals' characteristics (regulatory focus and chronotype) affect the device choice in order to carry out the search and purchase task in the context of e-retail. Lastly, as mobile and desktop channels differ in several terms such as size, weight, processing speed, navigation ease, internet speed, visual setting, and mobility ease, whereas search and purchase tasks also differ in term of time, effort, and cost associated with each stage. Therefore, it will be interesting to see how each individual characteristics e.g., chronotype (evening or morning) and regulatory focus (prevention or promotion) affect consumers' device choice to conduct search and purchase tasks. 


\section{Research Hypothesis}

The evening and morning type chronotypes have mobile and desktop usage patterns that are different. The literature shows that evening types are more habituated to online games, the internet, and mobile phones [20, 40]. Morning types favor traditional media and are less prone to using the latest technology [48]. In their work, Crowley et al. (2014) [49] stated that mobile phone emissions can delay sleeping cycles and that individuals with a later bedtime are more addicted to their mobile. The unique feature of mobile phones such as mobility, connectivity, and size offer a greater fit for evening types as they can receive instant recommendations, compare products and conclude a quick deal anywhere and at any time [15, 50]. Furthermore, mobiles and desktops also differ in time, place, and context, as mobiles offer quick and location-based searching and purchasing, image and voice search capability, continuous connectivity, and fast payment service. Consequently, it is possible that evening type chronotypes may prefer to use a mobile device for shopping. They may receive promotional content over their mobile, and they can react instantly. Later, they can visit the physical store for the final purchase if they desire. The literature confirms that impulsiveness is correlated with mobile phone usage wherein the shopper can search for and purchase the product quickly in order to satisfy their impulsive needs [51]. In their research, Cavallera and Giudici (2008) [52] and Adan, Natale, Caci, and Prat (2010) [53] confirmed that impulsivity is highly associated with evening types. Today, marketers are designing mobile marketing signals that cause impulse buying. Impulsive consumers respond favorably to these signals [54]. Accordingly, the mobile channel can attract more evening type consumers, so it can be hypothesized that:

H1: Mobile channel usage for searching and purchasing is higher for evening type than morning type consumers.

H2: Mobile channel usage is greater than desktop channels for searching and purchasing for evening type chronotype.

Furthermore, morning types are less impulsive, more thought-oriented, risk-minimizing and they evaluate the consequences of their behavior [55, 56]. They seek to obtain detailed information, recommendations, and evaluations in order to make decisions. Morning types prefer to follow their need for touch approach to reduce uncertainty and to increase their confidence in their judgment. In this regard, the desktop channel, with its exclusive benefits (enriched content, larger screen, easy navigation, efficient processing, high connectivity speed, high-resolution display, more capacity), offers a better fit to morning type consumers [57]. In contrast, the mobile channel offers less of a match for morning types as it has a small display, difficult navigation, and data limitations, which reduces the consumers' confidence in their judgment [15]. It is confirmed by the literature that haptic information increases the morning type chronotypes' confidence when it comes to decision making [58]. The desktop channel may attract more morning type consumers as it offers more haptic information than the mobile channel. Thus, it can be hypothesized that:

H3: Desktop channel usage for searching and purchasing is higher for morning type than evening type consumers.

H4: Desktop channel usage is greater than mobile channel use for searching and purchasing for the morning type chronotype.

Moreover, according to the regulatory focus theory, there are two different regulatory focuses (promotion \& prevention) [17]. Promotion-focused individuals orient themselves toward 
accomplishments, achievements, and development. They are more likely to be impulsive and have hedonic motives for shopping. They can make decisions with less and ambiguous information [41]. Additionally, hedonic motives offer entertainment, and emotional benefits to promotion-focused consumers, and searching for and viewing products on their mobile may provide them with instant hedonic pleasure [59]. Prevention-focused individuals are concerned more with protection and preventing negative consequences. They look for detailed information and prefer utilitarian motives. Furthermore, as prevention-focused consumers have utilitarian motives, they may perceive the mobile channel as problematic, insecure, and threatening [60]. Thus the desktop offers them a better fit for their needs. Prevention-focused shoppers look for detailed reviews, videos tutorials, and their friends' recommendation in order to increase their confidence in their judgments. The desktop's characteristics offer them these benefits in a superior way. According to the literature, consumers with hedonic purchase motives are promotion-focused. However, prevention-focused customers look for utilitarian shopping benefits [61]. It can be hypothesized that:

H5, promotion-focused consumers prefer the mobile channel over the desktop channel for shopping.

H6, prevention focused consumers prefer the desktop channel over the mobile channel for shopping.

\section{Methodology}

\subsection{Sample and data collection}

The sample consisted of the undergraduate and above level students who used Jindong and Taobao for shopping. According to Borak (2018) [37], in China, more than 85\% of online shopping is done by young consumers aged 17 to 36 . This indicates that most university-level students are digital shoppers and fall into this age range. Jindong and Taobao have over one billion active shoppers, and these two are the most famous and biggest online shopping retail platforms in China [37]. In the second quarter of 2017, online retail in China faced an increase in its volume and surpassed the US $\$ 132.40$ in value. University students were, therefore found to be the most appropriate respondents as they are tech-savvy and online shoppers. The convenience sampling technique was used to collect the data $\left(29^{\text {th }}\right.$ October 2017 to $15^{\text {th }}$ January 2018) as the respondents were accessible through the institutions' premises. Furthermore, with the support of a Chinese-English specialist survey, a questionnaire that was converted to Chinese was distributed to 15 scholars and 4 professors to gather their responses and suggestions. The suggested changes were made before the questionnaire was distributed to the actual sample. The link to the questionnaire was shared via a WeChat QR code, which directed the respondents to "wjx.cn"

Websites are a trusted online platform in China that can be used to collect data. WeChat is a famous social app with more than 1 billion users that is used for reasons including chatting, making payments, shopping, marketing, etc. The participants were given a 10 Yuan red-packet (a gift in the form of digital money on WeChat) and each device IP could submit the questionnaire only once. 


\subsection{Operationalization of the variables}

In the first stage, the participants provided their demographics and online shopping platform information. After that, the second part included chronotype, regulatory focus, and omnichannel process. The composite scale of Morningness (CSM) was used to measure the chronotype (morning, evening) of the respondents within the $10^{\text {th }}$ and $90^{\text {th }}$ percentiles [62]. The CSM scale consists of 13 Likert-scale items (with 3 items on a 5-point and 10 items on a 4-point scale) with a maximum of 55 possible from a minimum score of 13 . The cut-off points for the CSM scores in this study were 29 and 38, respectively. A score higher than 38 represents the individual being more of a morning type, and a score lower than 29 denotes the individual as being more of an evening type chronotype. The digital channel choice (mobile/desktop) in omnichannel process variable was taken from the study of [63]. The omnichannel process consists of four items that make up the desktop omnichannel process; asearching offline and purchasing desktop, b- searching desktop and purchasing offline, and the mobile omnichannel process, $\mathbf{c}$ - searching offline and purchasing via mobile and $\mathbf{d}$ - searching via mobile and purchasing offline ranked on a 5-point Likert scale (1- strongly disagree to 5 strongly agree). Finally, the construct of regulatory focus was measured by adapting the 10 item scale from [64]. See Appendix A.

\section{Findings}

In Table 1, the examined sample shows that the number of male and female respondents was almost equal. The majority of the sample used both e-retail channels for shopping, and most of them were Bachelor's or Masters’ degree, students.

Table 1. Respondents' Information

\begin{tabular}{lll}
\hline Demographics & Characteristics & Frequency Percentage \\
\hline Gender & Male & $49.22 \%$ \\
& Female & $50.78 \%$ \\
\hline Age in years & $18-23$ & $44.97 \%$ \\
& $24-29$ & $29.03 \%$ \\
& $30-35$ & $13.59 \%$ \\
& $36 \&$ above & $13.5 \%$ \\
\hline Degree & Undergraduate & $48.55 \%$ \\
& Master & $37.94 \%$ \\
& PhD & $12.41 \%$ \\
\hline Electronic retail & Taobao & $29.40 \%$ \\
& Jingdong & $6.89 \%$ \\
& Both & $63.71 \%$ \\
\hline Usage time & 1 Year & $8 \%$ \\
& 2 Year & $11.86 \%$ \\
& Above 2 years & $80.14 \%$ \\
\hline
\end{tabular}

Confirmatory Factor Analysis (CFA) was conducted in order to analyze the factors and structure of the important study constructs. The measurement model of the variables was developed by including chronotype, omnichannel, and regulatory focus. The findings revealed 
that the statistics of the measurement model fall within the recommended range $\left(\chi^{2} / \mathrm{df}=2.12\right.$ $\left(\chi^{2} / \mathrm{df}<3\right), \quad \mathrm{RMSEA}=0.047 \quad(\mathrm{RMSEA}<0.08), \quad \mathrm{CFI}=0.912 \quad(\mathrm{CFI}>0.90), \quad$ NNFI $=.926$ (NNFI $>0.90$ ). The factor loadings ranged between 0.622 and 0.724 , and only one item of regulatory focus variable scored 0.512 , however it was included in analysis as per the argument of Hair, Anderson, Tatham, and Black (1998) [65] and Hu and Bentler (1999) [66] that the factor loadings on each construct greater than 0.5 represent good factor structure and ensure convergent validity. Moreover, the composite reliability of each construct was greater than 0.8 . Hence, the reliability and validity of the study variables are also satisfactory. In order to test the relationship between the two types of chronotype and omnichannel, univariate analysis was conducted using SPSS. Initially, the chronotype types (i.e., morning and evening types) were segregated based on certain cut-off criteria [67]. Following the 10th and 90th percentiles, evening type constituted $40.24 \%(n=165)$, neither was equal to $24.14 \%(n=99)$ and morning type constituted $35.62 \%(n=146)$. After segregation, the mean differences of the groups were tested using the independent t-test. Both morning and evening types were significantly different from each other with $\mathrm{t}>2$ and $\mathrm{p}<0.05$ respectively. Furthermore, the morning and evening types were tested against mobile and desktop omnichannel. In Tables 2 and 3 , the findings show that evening types are more inclined toward the use of mobile omnichannel (Mean=3.85, $\mathrm{SD}=0.65$ ) compared to the morning types (Mean=2.61, $\mathrm{SD}=0.87$ ) with $\mathrm{F}>5$ and $\mathrm{p}<0.005$. These statistics confirm $\mathbf{H 1}$.

Table 2. Explanatory figures on mobile omnichannel use

\begin{tabular}{|c|c|c|c|c|c|c|c|c|}
\hline & \multirow[t]{2}{*}{$\mathrm{N}$} & \multirow[t]{2}{*}{ Mean } & \multirow[t]{2}{*}{$\begin{array}{l}\text { Std. } \\
\text { Deviation }\end{array}$} & \multirow[t]{2}{*}{$\begin{array}{l}\text { Std. } \\
\text { Error }\end{array}$} & \multicolumn{2}{|c|}{$\begin{array}{l}\text { 95\% Confidence } \\
\text { Interval for Mean }\end{array}$} & \multirow[t]{2}{*}{ Minimum } & \multirow[t]{2}{*}{ Maximum } \\
\hline & & & & & $\begin{array}{l}\text { Lower } \\
\text { Bound }\end{array}$ & $\begin{array}{l}\text { Upper } \\
\text { Bound }\end{array}$ & & \\
\hline Evening & 165 & 3.8567 & .65315 & .04834 & 3.6801 & 4.0232 & 1.00 & 5.00 \\
\hline Morning & 146 & 2.6123 & .87748 & .06157 & 2.8535 & 2.4811 & 1.00 & 5.00 \\
\hline Total & 311 & 3.3672 & .91571 & .05913 & 3.6250 & 3.6494 & 1.00 & 5.00 \\
\hline
\end{tabular}

Table 3. ANOVA findings on mobile channel use according to chronotype (evening versus morning)

\begin{tabular}{lllllll}
\hline & & $\begin{array}{l}\text { Sum of } \\
\text { Squares }\end{array}$ & $\mathrm{df}$ & $\begin{array}{l}\text { Mean } \\
\text { Square }\end{array}$ & $\mathrm{F}$ & Sig. \\
\hline \multirow{4}{*}{ Mobile Channel } & Between & 119.017 & 1 & 117.017 & 265.941 & .000 \\
& Groups & & & & & \\
& Within Groups & 143.928 & 309 & .495 & & \\
& Total & 256.945 & 310 & & & \\
\hline
\end{tabular}

Furthermore, in Tables 4 and 5, the findings show that morning types are more inclined toward the use of desktop omnichannel (Mean=3.75, $\mathrm{SD}=0.61$ ) compared to the evening types (Mean=2.87, $\mathrm{SD}=0.86$ ) with $\mathrm{F}>5$ and $\mathrm{p}<0.005$. 
Table 4. Explanatory figures on desktop omnichannel use

\begin{tabular}{|c|c|c|c|c|c|c|c|c|}
\hline & \multirow[t]{2}{*}{$\mathrm{N}$} & \multirow[t]{2}{*}{ Mean } & \multirow[t]{2}{*}{$\begin{array}{l}\text { Std. } \\
\text { Deviation }\end{array}$} & \multirow[t]{2}{*}{$\begin{array}{l}\text { Std. } \\
\text { Error }\end{array}$} & \multicolumn{2}{|c|}{$\begin{array}{l}95 \% \text { Confidence } \\
\text { Interval for Mean }\end{array}$} & \multirow[t]{2}{*}{ Minimum } & \multirow[t]{2}{*}{ Maximum } \\
\hline & & & & & $\begin{array}{l}\text { Lower } \\
\text { Bound }\end{array}$ & $\begin{array}{l}\text { Upper } \\
\text { Bound }\end{array}$ & & \\
\hline Morning & 146 & 3.7493 & .64112 & .05802 & 3.7849 & 3.7498 & 1.00 & 5.00 \\
\hline Evening & 165 & 2.8758 & .86095 & .06870 & 2.8149 & 3.1906 & 1.00 & 5.00 \\
\hline Total & 311 & 3.2859 & .86657 & .04791 & 3.8280 & 3.4387 & 1.00 & 5.00 \\
\hline
\end{tabular}

Table 5. ANOVA findings on online channel use according to chronotype (evening versus morning)

\begin{tabular}{|c|c|c|c|c|c|c|}
\hline & & $\begin{array}{l}\text { Sum of } \\
\text { Squares }\end{array}$ & $\overline{\mathrm{df}}$ & $\begin{array}{l}\text { Mean } \\
\text { Square }\end{array}$ & $\bar{F}$ & Sig. \\
\hline \multirow{3}{*}{$\begin{array}{l}\text { Online } \\
\text { Channel }\end{array}$} & Between Group & s57.110 & 1 & 56.110 & 104.989 & .000 \\
\hline & Within Groups & 169.088 & 309 & .550 & & \\
\hline & Total & 258.198 & 310 & & & \\
\hline
\end{tabular}

As shown in Table 6, pairwise comparison determined that the mean value of evening types is higher than morning types in their usage of mobile omnichannel (mean difference $=1.32, \mathrm{p}<$ 0.05 ) and evening types are also lesser when compared to morning types in terms of online-omnichannel (mean difference $=-0.864, \mathrm{p}<0.05$ ), confirming H2. Moreover, the pairwise comparison in Table 6 reveals that the mean value of morning types is higher in the desktop omnichannel process compared to the evening types (mean difference $=0.864, \mathrm{p}<$ 0.05 ) and that the morning types are lesser in the mobile omnichannel process compared to the evening types (mean difference $=-1.32, \mathrm{p}<0.05$ ), confirming $\mathbf{H 4}$.

Table 6. Pairwise Comparisons

\begin{tabular}{llllllll}
\hline $\begin{array}{l}\text { Dependent } \\
\text { Variable }\end{array}$ & $\begin{array}{l}\text { (I) } \\
\text { Chronotype }\end{array}$ & $\begin{array}{l}\text { Chronotype } \\
\end{array}$ & & $\begin{array}{l}\text { Mean } \\
\text { Difference } \\
\text { (I-J) }\end{array}$ & $\begin{array}{l}\text { Std. } \\
\text { Error }\end{array}$ & Sig. $^{\text {C }}$ & \multicolumn{2}{l}{$\begin{array}{l}\text { 95\% Confidence Interval } \\
\text { for Difference }\end{array}$} \\
\hline Mobile & Evening & Morning & 1.324 & .076 & .000 & 1.082 & 1.384 \\
& Morning & Evening & -1.324 & .076 & .000 & -1.385 & -1.084 \\
\multirow{2}{*}{ Online } & Evening & Morning & -.864 & .087 & .000 & -1.043 & -.702 \\
& Morning & Evening & .864 & .087 & .000 & .702 & 1.043 \\
\hline
\end{tabular}

Based on estimated marginal means

*. The mean difference is significant at the .05 level.

b. Adjustment for multiple comparisons: Least Significant Difference (equivalent to no adjustments).

In order to test hypotheses 5 and 6, two multiple regressions model were developed. In the first model, the predictors, promotion focus, and prevention focus were regressed against the mobile omnichannel. In the second model, promotion focus and prevention focus was 
regressed against the desktop omnichannel. Tables 7 and 8 show that both models have a better fit as the value of $\mathrm{F}$ is greater than 5 as $\mathrm{p}<0.05$. Table 7 shows that the beta coefficient from promotion focus to mobile omnichannel is positively significant $(\mathrm{p}<0.05)$. Moreover, this table shows that prevention focus has a significant negative relationship with mobile omnichannel. These statistics confirm hypothesis 5. Table 8 shows that the relationship between prevention focus and desktop omnichannel is positively significant $(p<0.05)$. Furthermore, the association between promotion focus and desktop omnichannel is negatively significant $(\mathrm{p}<0.05)$. These statistics confirm hypothesis 6 .

Table 7. Regression Model 1 (Regulatory Focus and Mobile Omnichannel)

\begin{tabular}{|c|c|c|c|c|c|c|c|}
\hline \multirow{2}{*}{\multicolumn{2}{|c|}{ Model }} & \multicolumn{2}{|c|}{$\begin{array}{c}\text { Un-standardized } \\
\text { Coefficients }\end{array}$} & \multirow{2}{*}{$\begin{array}{c}\text { Standardized } \\
\text { Coefficients } \\
\text { Beta } \\
\end{array}$} & \multirow[b]{2}{*}{$\mathrm{t}$} & \multirow[b]{2}{*}{ Sig. } & \multirow[b]{2}{*}{ F-value } \\
\hline & & B & Std. Error & & & & \\
\hline \multirow[t]{3}{*}{1} & (Constant) & 3.797 & .291 & & 13.030 & .000 & 9.99 \\
\hline & $\begin{array}{l}\text { Promotion } \\
\text { Focus }\end{array}$ & .145 & .062 & .130 & 2.343 & .020 & \\
\hline & $\begin{array}{l}\text { Prevention } \\
\text { Focus }\end{array}$ & -.253 & .063 & -.225 & -4.043 & .000 & \\
\hline
\end{tabular}

a. Dependent Variable: Mobile Omnichannel

Table 8. Regression Model 2 (Regulatory Focus and Desktop omnichannel)

\begin{tabular}{|c|c|c|c|c|c|c|c|}
\hline \multirow[b]{2}{*}{ Mode } & & \multicolumn{2}{|c|}{$\begin{array}{l}\text { Un-standardized } \\
\text { Coefficients }\end{array}$} & \multirow{2}{*}{$\begin{array}{c}\text { Standardized } \\
\text { Coefficients } \\
\text { Beta } \\
\end{array}$} & \multirow[b]{2}{*}{$\mathrm{t}$} & \multirow[b]{2}{*}{ Sig. } & \multirow[b]{2}{*}{ F-value } \\
\hline & & B & Std. Error & & & & \\
\hline \multirow[t]{3}{*}{1} & (Constant) & 2.831 & .278 & & 10.193 & .000 & 11.22 \\
\hline & $\begin{array}{l}\text { Promotion } \\
\text { Focus }\end{array}$ & -.123 & .059 & -.116 & -2.091 & .037 & \\
\hline & $\begin{array}{l}\text { Prevention } \\
\text { Focus }\end{array}$ & 267 & .060 & 249 & 4.488 & .000 & \\
\hline
\end{tabular}

a. Dependent Variable: Desktop omnichannel

Finally, the hypotheses summary is as follows in Table 9.

Table 9. Hypotheses Summation

\begin{tabular}{|c|c|c|c|}
\hline Hypotheses No. & Association & & Results \\
\hline H1 & $\begin{array}{l}\text { Evening chronotype } \rightarrow \text { mobile omnichannel } \\
\text { omnichannel }\end{array}$ & $>$ desktop & Supported \\
\hline $\mathrm{H} 2$ & $\begin{array}{l}\text { Evening chronotype }>\text { morning-chronotype } \\
\text { omnichannel }\end{array}$ & $\rightarrow$ mobile & Supported \\
\hline H3 & $\begin{array}{l}\text { Morning chronotype } \rightarrow \text { desktop omnichannel } \\
\text { omnichannel }\end{array}$ & $>$ mobile & Supported \\
\hline $\mathrm{H} 4$ & $\begin{array}{l}\text { Morning- chronotype > Evening- chronotype } \\
\text { omnichannel }\end{array}$ & $\rightarrow$ desktop & Supported \\
\hline H5 & Regulatory Focus (Promotion Vs. Prevention) & $\rightarrow$ mobile & Supported \\
\hline
\end{tabular}




\section{Discussion}

In the present age, consumers possess several digital devices, notably mobiles and desktop computers. They use these devices to search, evaluate, purchase and recommend the product in a fast-growing e-retail world. Omnichannel is a relatively new and growing field, and businesses are struggling to cope with this evolution. Thus this study contributes to the literature of consumer behavior by incorporating the interesting and neglected variables of regulatory focus and chronotype in the omnichannel context. Individual differences shape behavior and this study also confirm this claim. The findings show that evening types like to use the mobile channel for shopping and that the promotion focus moderates this relationship positively. These results are in line with the study of Rodríguez-Torrico, San José Cabezudo, and San-Martín (2017) [63], which proves that high impulsive consumers prefer the mobile channel compared to low impulsive shoppers, and it has been shown that evening types are impulsive. Furthermore, another explanation for the evening types' mobile channel preference is that mobile offers them the ability to a quick search, evaluate and purchase and payment facilities that satisfy their instant and impulsive need [24, 68-70]. The evening types' seek hedonic pleasure mostly, and shopping via mobile channel offers them such benefits. Furthermore, charactersitics of the mobile channel (size, quick access, internet connectivity, fast payment) and traits of evening type chronotypes' (high mobile usage, impulsive, hedonic benefit seeker) offer a better fit to conduct search and purchase tasks via the mobile channel. Moreover, Promotion-focused is positively associated with mobile channels, and as such, the consumers are risk takers, innovation seekers, and more impulsive [18, 71, 72].

In contrast, the desktop channel offers a better task-technology fit for morning types. It satisfies their haptic information need by offering detailed information. The larger screen, easy navigation, fast connectivity, enriched content, video capability, and image reviews can be the reason for the morning types preferring the desktop channel. These findings are also in line with the previous work of $[24,25,73]$ which stated that morning types are less likely to be risk-takers, less impulsive, and detailed information seekers. Furthermore, characteristics of the desktop channel (larger screen, easy navigation, video capability, and image reviews) and traits of morning type chronotypes' (less impulsive, detailed information seeker, utilitarian benefits seeker) offer a better fit to conduct search and purchase tasks via the desktop channel. Moreover, the prevention focus positively affects the desktop channel choice. Prevention-focused consumers have utilitarian and haptic information needs, and they thus look for detailed reviews, HD videos, images, and social circles recommendations in order to minimize the risk and undesired consequences of their decisions, so the desktop channel is an optimal choice for them [18, 71, 72].

This study offers an interesting contribution to the literature by confirming that, first, regulatory focus and chronotype are relevant to consumer decision-making as a part of an omnichannel strategy. Second, regulatory focus and chronotype affect channel choice in the search and purchase stages and prove that individual characteristics and personality difference influence the task-technology fit. Furthermore, consumers with promotion motivation prefer mobile to pursue their shopping goal and consumers with prevention motivation use the desktop channel for shopping purpose. 


\section{Conclusions}

This study offers theoretical inputs in many distinct ways. First, it expands the TTF theory in channel choice and e-retail context. Second, while previous studies on TTF mostly focus on technology characteristics this research incorporates individual characteristics construct too which helps to better understand consumer decision making in online shopping. Third, while prior studies on chronotype are in health, medical and educational sector this work extends the chronotype literature in a marketing context. Furthermore, this study opens new avenues for further research on chronotype in different consumer behavior domains. Fourth, the regulatory focus construct is newly introduced in the marketing context and this study expands the regulatory focus literature by investigating it in channel choice context. Fifth, the results show that the mobile channel is the optimal choice of evening chronotype and promotion focus consumers. The greater use and familiarity with mobile devices, impulsive nature, tendency to adopt new things and seeking hedonic pleasure from shopping through mobile devices can be the reason for mobile channel choice for such type of customers [56, 74, 75]. Whereas, morning chronotype and prevention focus consumers' prefer desktop channel. The desire to minimize the risk associated with their actions, tendency to seek detailed information to make a decision, more control over impulse behavior and utilitarian benefits motivation [56, 74, 75], can be the reason for desktop channel choice for such shoppers. Finally, the findings showed that individuals' characteristics (evening or morning; prevention or promotion focus) are a significant predictor of task-technology fit and consumers' channel choice in e-retail.

In addition, with the rapid innovation of technology, consumer behavior is becoming complex, and businesses are struggling to develop an effective marketing strategy. Consumers are using several digital devices as a part of the purchase cycle, and it is essential to understand their journey. As evening types and promotion-focused customers are more impulsive by nature, companies can target them by offering a quick and easy search and purchase options by introducing fewer check-in and check-out points, thus requiring less information on either their website or their app. Furthermore, location-based marketing signals can be designed to attract evening type customers. As evening type people use mobile devices late at night, and they are at their peak arousal point in the evening, marketers should target them at that time to receive a favorable response. Furthermore, evening types suffer from many health-related issues like insomnia, obesity and late-night food cravings so that marketers can approach them via the mobile channel effectively with health-related products like a gym membership, fitness apps, and healthy diet plans. Evening types are more promotion-focused, so they favor hedonic motives. Companies can tailor their offers and messages (SMS, MMS, and websites) accordingly.

Moreover, morning types and prevention focus consumers are well organized and require haptic information in order to make their judgments. They have a risk prevention focus, and as a result, they are not very open to sharing their location and private information. As this study confirmed that morning type and prevention-focused shoppers prefer the desktop channel for searching and purchase, marketers need to tailor their offerings accordingly. The companies can offer HD videos, pictures of the product, reviews, product endorsements by trustworthy celebrities, trial versions offerings, a secure warranty and guarantee, and secure payment facilities in order to yield a positive response from morning type consumers.

Also, mobile channel users normally open fewer web pages and use few evaluation options, keeping the in view that mobile channels users are mostly evening type and promotion-focused the marketers can customize their webpages and product comparison 
options accordingly. Whereas desktop users (morning and prevention-focused) open more webpages for information search and comparing products offerings, the web managers can customize their offers accordingly.

Another interesting implication for evening type and promotion-focused consumer is coupons offer. Coupons are forms of price discount offered to customers, and the mobile channel is the right option for coupon offering to even type, and promotion-focused consumers on receiving a favorable response. To target, the morning type and prevention-focused customers desktop channel offers a better fit, as it can reduce search and time cost and also it can reduce perceived risk for customers who may yield favorable response for marketing efforts. Furthermore, the trial versions of products are better to offer at the mobile channel to receive quick adoption and feedback from such channel users. Furthermore, different companies especially, tourism companies and airline companies, can target morning type and prevention-focused consumers via desktop channels as they plan their trip long before to travel [76]. Whereas, last time offers which need quick sale can be tailored and offered on the mobile channel.

However, there are some limitations to this research. In contrast to the Western world, the level of mobile device usage is high in China for shopping. Replicating this study in other countries can reveal varied findings. Online shopping was considered in general in this study, but future research can use a specific product category. While present research focuses only on mobile and desktop channel (because of research limitation) the future work can investigate offline and more online channels. As regulatory focus and chronotype are newly introduced concepts in the marketing and business fields, not much literature data was available. However, this also shows the importance of this research. Finally, all types of chronotype should be studied in future research in order to provide a better understanding of the consumer's personality impact on channel choice.

\section{References}

[1] Verhoef, P.C., P.K. Kannan, and J.J., "Inman, From multi-channel retailing to omni-channel retailing: introduction to the special issue on multi-channel retailing," Journal of retailing, 91(2), p. 174-181, 2015. Article (CrossRef Link).

[2] Venkatesan, R., V. Kumar, and N., "Ravishanker, Multichannel shopping: causes and consequences," Journal of Marketing, 71(2), p. 114-132, 2007. Article (CrossRef Link).

[3] Ansari, A., C.F. Mela, and S.A. Neslin, "Customer channel migration," Journal of marketing research, 45(1), p. 60-76, 2008.

[4] Dholakia, U.M., et al., "Consumer behavior in a multichannel, multimedia retailing environment," Journal of Interactive Marketing, 24(2), p. 86-95, 2010.

Article (CrossRef Link).

[5] Lazaris, C. and A. Vrechopoulos, "From multi-channel to "omnichannel” retailing: review of the literature and calls for research," in Proc. of 2nd International Conference on Contemporary Marketing Issues,(ICCMI), 2014.

[6] Juaneda-Ayensa, E., A. Mosquera, and Y, "Sierra Murillo, Omnichannel Customer Behavior: Key Drivers of Technology Acceptance and Use and Their Effects on Purchase Intention," Front Psychol, 7, p. 1117, 2016. Article (CrossRef Link).

[7] Blom, A., F. Lange, and R.L. Hess Jr, "Omnichannel-based promotions' effects on purchase behavior and brand image," Journal of Retailing and Consumer Services, 39, p. 286-295, 2017. Article (CrossRef Link).

[8] Chou, Y.-H.D., T.-Y.D. Li, and C.-T.B. Ho, "Factors influencing the adoption of mobile commerce in Taiwan," International Journal of Mobile Communications, 16(2), p. 117-134, 2018. Article (CrossRef Link). 
[9] Heo, J. and C.-W. Chang, "Factors influencing intention to accept location-based mobile advertising among young mobile user segments: a social exchange perspective," International Journal of Mobile Communications, 16(6), p. 607-623, 2018.

Article (CrossRef Link).

[10] Hsu, C.-W. and C.-C. Yeh, "Understanding the critical factors for successful M-commerce adoption," International Journal of Mobile Communications, 16(1), p. 50-62, 2018.

Article (CrossRef Link).

[11] Waheed, A. and J. Yang, "The impact of mobile marketing on online consumer buying behaviour: empirical evidence from Pakistan," International Journal of Mobile Communications, 16(6), p. 624-643, 2018. Article (CrossRef Link).

[12] Deloitte, "Navigating the new digital divide. A global summary of findings from nine countries on digital influence in retail," 2016 [cited 20185 March]; Available from: https://www2.deloitte.com/global/en/pages/consumer-business/articles/gx-global-digital-div ide-retail.html.

[13] Hübner, A., J. Wollenburg, and A. Holzapfel, "Retail logistics in the transition from multi-channel to omni-channel," International Journal of Physical Distribution \& Logistics Management, 46(6/7), p. 562-583, 2016. Article (CrossRef Link).

[14] Yang, K. and H.-Y. Kim, "Mobile shopping motivation: an application of multiple discriminant analysis," International Journal of Retail \& Distribution Management, 40(10), p. 778-789, 2012. Article (CrossRef Link).

[15] Gao, L., K.A. Waechter, and X. Bai, "Understanding consumers' continuance intention towards mobile purchase: A theoretical framework and empirical study - A case of China," Computers in Human Behavior, 53, p. 249-262, 2015. Article (CrossRef Link).

[16] Holmes, A., A. Byrne, and J. Rowley, "Mobile shopping behaviour: insights into attitudes, shopping process involvement and location," International Journal of Retail \& Distribution Management, 42(1), p. 25-39, 2014. Article (CrossRef Link).

[17] Higgins, E.T., "Promotion and prevention: Regulatory focus as a motivational principle, in Advances in experimental social psychology," Advances in Experimental Social Psychology, vol. 30, p. 1-46, 1998. Article (CrossRef Link).

[18] Werth, L. and J. Foerster, "How regulatory focus influences consumer behavior," European Journal of Social Psychology, 37(1), p. 33-51, 2007. Article (CrossRef Link).

[19] Tonetti, L., M. Fabbri, and V. Natale, "Relationship between circadian typology and big five personality domains," Chronobiology international, 26(2), p. 337-347, 2009.

Article (CrossRef Link).

[20] Randler, C., M.B. Horzum, and C. Vollmer, "Internet addiction and its relationship to chronotype and personality in a Turkish university student sample," Social science computer review, 32(4), p. 484-495, 2014. Article (CrossRef Link).

[21] Arnold, M.J. and K.E. Reynolds, "Affect and retail shopping behavior: Understanding the role of mood regulation and regulatory focus," Journal of Retailing, 85(3), p. 308-320, 2009. Article (CrossRef Link).

[22] Das, G., "Retail shopping behaviour: understanding the role of regulatory focus theory," The International Review of Retail, Distribution and Consumer Research, 25(4), p. 431-445, 2015. Article (CrossRef Link).

[23] Natale, V., A. Alzani, and P. Cicogna, "Cognitive efficiency and circadian typologies: a diurnal study," Personality and Individual differences, 35(5), p. 1089-1105, 2003.

Article (CrossRef Link).

[24] Horzum, M.B. and E. Demirhan, "The role of chronotype on Facebook usage aims and attitudes towards Facebook and its features," Computers in Human Behavior, 73, p. 125-131, 2017. Article (CrossRef Link).

[25] Díaz-Morales, J.F., "Morning and evening-types: Exploring their personality styles," Personality and Individual Differences, 43(4), p. 769-778, 2007. Article (CrossRef Link).

[26] Reddy, A.B. and J.S. O'Neill, "Healthy clocks, healthy body, healthy mind," Trends Cell Biol, 20(1), p. 36-44, 2010. Article (CrossRef Link). 
[27] Gullo, K., et al., "Does Time of Day Affect Variety-Seeking?," Journal of Consumer Research, vol. 46, no. 1, pp. 20-35, 2019. Article (CrossRef Link).

[28] Hornik, J. and G. Miniero, "Synchrony effects on customers' responses and behaviors," International Journal of Research in Marketing, 26(1), p. 34-40, 2009.

Article (CrossRef Link).

[29] Boesen-Mariani, S., P. Gomez, and M.-L. Gavard-Perret, "L'orientation régulatrice: un concept prometteur en marketing," Recherche et Applications en Marketing (French Edition), 25(1), p. 87-106, 2010. Article (CrossRef Link).

[30] Florack, A., M. Scarabis, and S. Gosejohann, "Regulatory focus and consumer information processing," Applying social cognition to consumer-focused strategy, p. 235-263, 2005.

[31] Goodhue, D.L. and R.L. Thompson, "Task-technology fit and individual performance," MIS quarterly, vol. 19, no. 2, p. 213-236, 1995. Article (CrossRef Link).

[32] Yen, D.C., et al., "Determinants of users' intention to adopt wireless technology: An empirical study by integrating TTF with TAM," Computers in Human Behavior, 26(5), p. 906-915, 2010. Article (CrossRef Link).

[33] Gebauer, J. and Y. Tang, "Applying the theory of task-technology fit to mobile technology: the role of user mobility," International Journal of Mobile Communications, 6(3), p. 321-344, 2008. Article (CrossRef Link).

[34] Chen, Y.-S. and S.Y. Huang, "The effect of task-technology fit on purchase intention: The moderating role of perceived risks," Journal of Risk Research, 20(11), p. 1418-1438, 2017. Article (CrossRef Link).

[35] Lee, C.-C., H.K. Cheng, and H.-H. Cheng, "An empirical study of mobile commerce in insurance industry: Task-technology fit and individual differences," Decision Support Systems, 43(1), p. 95-110, 2007. Article (CrossRef Link).

[36] Overby, E.M. and B. Konsynski, "Task-technology fit and process virtualization theory: an integrated model and empirical test," Emory Public Law Research Paper No. 10-96, 2010. Article (CrossRef Link).

[37] Borak, M., "Data shows 2017 was the year of e-commerce apps: report," 2018 [cited 2018 Jan 31]; Available from: https://technode.com/2018/01/31/2017-e-commerce-apps.

[38] Rouis, S., M. Limayem, and E. Salehi-Sangari, "Impact of Facebook Usage on Students' Academic Achievement: Role of self-regulation and trust," 2011.

[39] Tandoc, E.C., P. Ferrucci, and M. Duffy, "Facebook use, envy, and depression among college students: Is facebooking depressing?," Computers in Human Behavior, 43, p. 139-146, 2015. Article (CrossRef Link).

[40] Vollmer, C., et al., "Computer game addiction in adolescents and its relationship to chronotype and personality," Sage Open, 4(1), p. $2158244013518054,2014$. Article (CrossRef Link).

[41] Semin, G.R., et al., "Linguistic signatures of regulatory focus: how abstraction fits promotion more than prevention," Journal of personality and social psychology, 89(1), p. 36-45, 2005. Article (CrossRef Link).

[42] Rapp, A., et al., "Perceived customer showrooming behavior and the effect on retail salesperson self-efficacy and performance," Journal of Retailing, 91(2), p. 358-369, 2015. Article (CrossRef Link).

[43] Rodríguez-Torrico, P., R.S.J. Cabezudo, and S. San-Martín, "Tell me what they are like and I will tell you where they buy. An analysis of omnichannel consumer behavior," Computers in Human Behavior, 68, p. 465-471, 2017. Article (CrossRef Link).

[44] Kazancoglu, I. and H. Aydin, "An investigation of consumers' purchase intentions towards omni-channel shopping: A qualitative exploratory study," International Journal of Retail \& Distribution Management, 46(10), p. 959-976, 2018. Article (CrossRef Link).

[45] Verhoef, P.C., P.K. Kannan, and J.J. Inman, "From Multi-Channel Retailing to Omni-Channel Retailing," Journal of Retailing, 91(2), p. 174-181, 2015.

Article (CrossRef Link). 
[46] Vera, D., et al., "Thinking Before Acting'or 'Acting Before Thinking': Antecedents of Individual Action Propensity in Work Situations," Journal of Management Studies, 51(4), p. 603-633, 2014. Article (CrossRef Link).

[47] Gupta, A. and N. Arora, "Consumer adoption of m-banking: a behavioral reasoning theory perspective," International Journal of Bank Marketing, 35(4), p. 733-747, 2017.

Article (CrossRef Link).

[48] Nimrod, G., "Early birds and night owls: Differences in media preferences, usages, and environments," International Journal of Communication, 9, p. 21, 2015.

[49] Crowley, S.J., et al., "A longitudinal assessment of sleep timing, circadian phase, and phase angle of entrainment across human adolescence," PloS one, 9(11), p. e112199, 2014. Article (CrossRef Link).

[50] Wang, R.J.-H., E.C. Malthouse, and L. Krishnamurthi, On the Go: How Mobile Shopping Affects Customer Purchase Behavior, Journal of Retailing, 91(2), p. 217-234, 2015. Article (CrossRef Link).

[51] Drennan, J. and G. Mort, "Examination of the influence of personal attributes on consumer use on m-services," 2003.

[52] Cavallera, G.M. and S. Giudici, "Morningness and eveningness personality: A survey in literature from 1995 up till 2006," Personality and Individual Differences, 44(1), p. 3-21, 2008. Article (CrossRef Link).

[53] Adan, A., et al., "Relationship between circadian typology and functional and dysfunctional impulsivity," Chronobiol Int, 27(3), p. 606-19, 2010. Article (CrossRef Link).

[54] San-Martin, S. and B. López-Catalán, "How can a mobile vendor get satisfied customers?," Industrial Management \& Data Systems, 113(2), p. 156-170, 2013. Article (CrossRef Link).

[55] Hogben, A.L., et al., "Conscientiousness is a predictor of diurnal preference," Chronobiol Int, 24(6), p. 1249-1254, 2007. Article (CrossRef Link).

[56] Nowack, K. and E. van der Meer, "Are larks future-oriented and owls present-oriented? Ageand sex-related shifts in chronotype-time perspective associations," Chronobiol Int, 30(10), p. 1240-1250, 2013. Article (CrossRef Link).

[57] Ozok, A.A. and J. Wei, "An empirical comparison of consumer usability preferences in online shopping using stationary and mobile devices: results from a college student population," Electronic Commerce Research, 10(2), p. 111-137, 2010. Article (CrossRef Link).

[58] Peck, J. and T.L. Childers, "To have and to hold: The influence of haptic information on product judgments," Journal of Marketing, 67(2), p. 35-48, 2003. Article (CrossRef Link).

[59] Arnold, M.J. and K.E. Reynolds, "Hedonic shopping motivations," Journal of retailing, 79(2), p. 77-95, 2003. Article (CrossRef Link).

[60] Nepomuceno, M.V., M. Laroche, and M.-O. Richard, "How to reduce perceived risk when buying online: The interactions between intangibility, product knowledge, brand familiarity, privacy and security concerns," Journal of Retailing and Consumer Services, 21(4), p. 619-629, 2014. Article (CrossRef Link).

[61] Khajehzadeh, S., H. Oppewal, and D. Tojib, "Consumer responses to mobile coupons: The roles of shopping motivation and regulatory fit," Journal of Business Research, 67(11), p. 2447-2455, 2014. Article (CrossRef Link).

[62] Önder, İ., Ş. Beşoluk, and M.B. Horzum, "Psychometric properties of the Turkish version of the Composite Scale of Morningness," The Spanish journal of psychology, 16, 2013. Article (CrossRef Link).

[63] Rodríguez-Torrico, P., R. San José Cabezudo, and S. San-Martín, "Tell me what they are like and I will tell you where they buy. An analysis of omnichannel consumer behavior," Computers in Human Behavior, 68, p. 465-471, 2017. Article (CrossRef Link).

[64] Haws, K.L., U.M. Dholakia, and W.O. Bearden, "An assessment of chronic regulatory focus measures," Journal of Marketing Research, 47(5), p. 967-982, 2010. Article (CrossRef Link).

[65] Hair, J., et al., Multivariate data analysis4, Prentice-Hall Englewood Cliffs, NJ, 1998,. 
[66] Hu, L.t. and P.M. Bentler, "Cutoff criteria for fit indexes in covariance structure analysis: Conventional criteria versus new alternatives," Structural equation modeling: a multidisciplinary journal, 6(1), p. 1-55, 1999. Article (CrossRef Link).

[67] Smith, C.S., C. Reilly, and K. Midkiff, "Evaluation of three circadian rhythm questionnaires with suggestions for an improved measure of morningness," Journal of Applied psychology, 74(5), p. 728, 1989. Article (CrossRef Link).

[68] Barwitz, N. and P. Maas, "Understanding the Omnichannel customer journey: determinants of interaction choice," Journal of interactive marketing, 43, p. 116-133, 2018.

Article (CrossRef Link).

[69] Song, J. and H. Qu, "How does consumer regulatory focus impact perceived value and consumption emotions?," International Journal of Contemporary Hospitality Management, 31(1), p. 285-308, 2019. Article (CrossRef Link).

[70] Zheng, X., et al., "Understanding impulse buying in mobile commerce: An investigation into hedonic and utilitarian browsing," International Journal of Information Management, 48, p. 151-160, 2019. Article (CrossRef Link).

[71] van Noort, G., P. Kerkhof, and B.M. Fennis, "Online versus conventional shopping: Consumers' risk perception and regulatory focus," CyberPsychology \& Behavior, 10(5), p. 731-733, 2007. Article (CrossRef Link).

[72] Yim, M.Y.-C., et al., "Hedonic shopping motivation and co-shopper influence on utilitarian grocery shopping in superstores," Journal of the Academy of Marketing Science, 42(5), p. 528-544, 2014. Article (CrossRef Link).

[73] Demirhan, E., C. Randler, and M.B. Horzum, "Is problematic mobile phone use explained by chronotype and personality?," Chronobiol Int, 33(7), p. 821-31, 2016.

Article (CrossRef Link).

[74] Blachnio, A., A. Przepiorka, and J.F. Diaz-Morales, "Facebook use and chronotype: Results of a cross-sectional study," Chronobiol Int, 32(9), p. 1315-9, 2015. Article (CrossRef Link).

[75] Kang, J.I., et al., "Circadian preference and trait impulsivity, sensation-seeking and response inhibition in healthy young adults," Chronobiology international, 32(2), p. 235-241, 2015. Article (CrossRef Link).

[76] Côté-Hamel, M., "Tell Me at What Time You Usually Wake Up, I’ll Tell You What Type of Traveler You Are: An Investigation of the Relationship Between Destination Canada “Explorer Quotient” Segmentation Method and Chronotype," 2016.

\section{Appendix}

\section{Appendix A. Variable Operationalization}

\begin{tabular}{ll}
\hline Variable & Adopted from \\
\hline Regulatory Focus & The construct of regulatory focus was measured by adapting \\
& the 10 item scale from Haws 2010.
\end{tabular}

Chronotype The composite scale of Morningness (CSM) was used to measure the chronotype (morning, evening) of the respondents taken from Smith (1989) and Ondor, (2013). The CSM scale consists of 13 Likert-scale items (with 3 items on a 5-point and 10 items on a 4-point scale) with a maximum of 55 possible from a minimum score of 13 .

Device Choice in The digital channel choice (mobile/desktop) in omnichannel Omnichannel process variable was taken from the study of Rodríguez-Torrico, San José Cabezudo, (2018), ranked on a 5-point Likert scale (1- strongly disagree to 5 - strongly agree). 


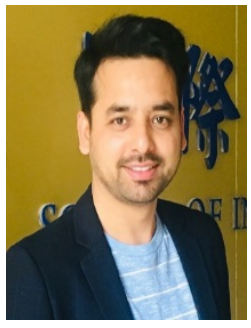

Syed Waqar Haider is a PhD scholar at School of Management, Xi'an Jiaotong University, China. His research interests focus on consumer behavior \& psychology, retailing, social media and digital marketing. He also holds MBA in Marketing and his research articles have been published in well-known journals.

Email:sw_rizvi@hotmail.com

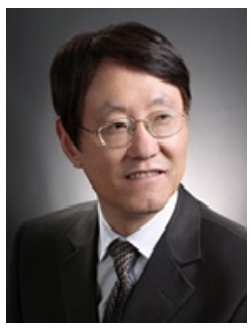

Guijun Zhuang, Ph.D., is a Professor and the Head of Marketing department at School of Management, Xi'an Jiaotong University, China. He received his PhD degree in Marketing from City University of Hong Kong. His current research interests include marketing channel governance, relationship marketing, marketing ethics and internet marketing. His research articles have been published in well renowed journals.

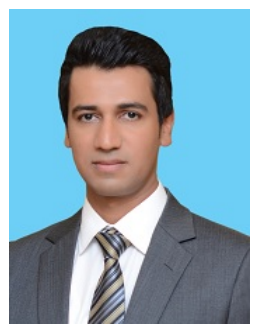

Amir Ikram is serving as an Assistant Professor at IB\&M, University of Engineering \& Technology, Lahore, Pakistan. He received his PhD from School of Management, Xi'an Jiaotong University, China (an AACSB-accredited school). He has published many research papers in reputed international Journals. His research interests lie in entrepreneurship, cluster strategy, supply chain management, technology management, additive manufacturing and regional development.

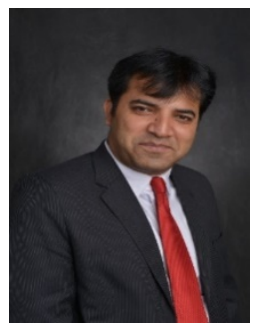

Bilal Anwar is an Assistant Professor in Leadership \& Management Sciences department at National Defence University, Islamabad Pakistan. He did his PhD from School of Management, Xi'an Jiao tong University, China. His interests lie in public private partnership, leadership strategies and regional development. He has vast industrial experience of more than 10 years in the leadership position at various multinational banks and corporations in Pakistan. 